\title{
The primitively social behavior of Euglossa cordata (Hymenoptera, Apidae, Euglossini): a view from the perspective of kin selection theory and models of reproductive skew
}

\author{
Gabriele Antico Freiria $^{1}$, Carlos Alberto Garófalo ${ }^{2}$, Marco Antonio Del Lama ${ }^{1}$ \\ ${ }^{1}$ Departamento de Genética e Evolução, Universidade Federal de São Carlos, Rodovia Washington Luiz km 235, \\ 13565.905, São Carlos, São Paulo, Brazil \\ ${ }^{2}$ Departamento de Biologia, Faculdade de Filosofia, Ciências e Letras de Ribeirão Preto, USP, Ribeirão Preto, SP 14040- \\ 901, Brazil
}

Received 18 July 2016 - Revised 6 December 2016 - Accepted 17 January 2017

\begin{abstract}
The present study investigated the level of reproductive skew during the reactivation processes of 11 nests of Euglossa cordata. Behavioral observations associated with kinship analysis between offspring and females involved in these processes were carried out. Different types of associations between females occurred in these reactivations: between mothers and daughters, sisters, cousins, and unrelated females. Behavioral observations and Mendelian segregation analysis at 12 microsatellite loci attributed all the offspring to the dominant female of each nest. The results revealed a full reproductive skew at the different processes of reactivation, irrespective of the type of association between females. Thus, our data indicate that reproductive skew was not associated with genetic relatedness in E. cordata.
\end{abstract}

\section{Euglossa / reproductive skew / sociogenetic structure / microsatellites}

\section{INTRODUCTION}

Social behavior is a controversial issue in biology, as it involves the evolution by natural selection of altruistic traits, which decreases individual fitness (Freeman and Herron 2009). Models were proposed to solve this apparent paradox, such as kin selection theory (Hamilton 1964), surely the model that received greater attention among researchers (Queller and Strassmann 1998; Keller and Chapuisat 1999; Strassmann et al. 2011; Liao et al. 2015).

Electronic supplementary material The online version of this article (doi:10.1007/s13592-017-0496-4) contains supplementary material, which is available to authorized users.

Corresponding author: G. Freiria, gfreiria@gmail.com

Manuscript editor: David Tarpy
According to kin selection theory, the evolution of altruistic behavior, which includes the reproductive division of labor, is favored by genetic relatedness among nestmates. It is possible to gain reproductive success by providing reproductive opportunities to relatives. As related individuals share alleles by descent, when an individual helps their relatives to reproduce, they indirectly pass on genes identical by descent to the next generation, what Hamilton (1964) named indirect fitness. However, the occurrence of conflicts within groups is not excluded, since individuals may be interested in passing on their genes directly to the next generation (Keller and Chapuisat 1999).

Theoretical models have been proposed to explain how such conflicts can be solved. Reproductive skew models involve ecological and genetic predictions to explain the different reproductive skew rates seen in animal societies (Reeve and Keller 2001). 
Investigations about factors or conditions that favor the evolution of social behavior require presocial taxa (Rehan et al. 2015). Orchid bees are appropriate models, as such insects are the only clearly non-eusocial species within the monophyletic group of corbiculate bees that clusters honeybees, stingless bees, bumblebees, and orchid bees.

Among the free-living (Euglossa, Eulaema, and Eufriesea) and cleptoparasitic genera (Aglae and Exaerete) of the tribe Euglossini (Michener 2007), Euglossa is the most suitable for studying the evolution of social behavior, since this genus harbors both solitary and communal species, as well as species in which two or more females share a nest where reproductive division of labor and overlapping generations are observed (Garófalo 2006; Augusto and Garófalo 2011).

The genus Euglossa has approximately 110 described species (Ramírez et al. 2010); the intranidal observations are known or suggested for about $10 \%$ of them. Among these species, the social organization of Euglossa cordata has been the most extensively studied. Nest foundation is a solitary process. After building six to ten cells, the foundress female remains in the nest until the emergence of her offspring (Garófalo 1985; Augusto and Garófalo 2011). Subsequently, some young females remain in the natal nest, reactivating it in either the presence or absence of the mother. Thus, small colonies are formed by females of different generations (mother and daughter), the same generation (sisters), and occasionally by unrelated females. Behavioral observations in E. cordata nests showed that the oldest female assumes dominance of the nest. The dominant female (DF) rarely leaves the nest, while the subordinate female (SF) assumes the tasks of colleting resin, constructing or reusing cells, provisioning cells and laying eggs.

The DF performs oophagy of the subordinate's eggs and replaces her own eggs in the previously operculated cells, suggesting complete reproductive skew (Garófalo 1985, 1992; Augusto and Garófalo 2011). However, studies based only on behavioral observations do not fully account for genetic relatedness estimates of reproductive skew. Nests need to be monitored constantly so that all offspring could be assigned accurately to the DF or SF. Thus, behavioral observations followed by kinship analysis can provide better estimates of reproductive skew rate in all types of associations between reactivating females, to verify if genetic relatedness and reproductive division of labor are correlated in Euglossa species.

The aim of this study was to confirm the occurrence of complete reproductive skew in E. cordata through behavioral observations and kinship analyses using microsatellite markers in females and offspring. We also discuss the evolution of reproductive work division in Euglossa comparing the results found in some species of the genus on the basis of the predictions of kin selection theory and models of reproductive skew.

\section{MATERIAL AND METHODS}

Reactivation processes were monitored in 13 E. cordata nests until adequate conditions for estimating reproductive skew rates in the offspring production by reactivating females were obtained. These situations consisted of reactivations where more than one female is involved and more than one type of association between females. A specific number of cells produced during reactivation was also needed to allow accurate estimates of reproductive skew based on male and female offsprings. A minimum of six cells was established as appropriate for the genetic analysis in the present investigation.

\subsection{Obtaining of nests}

To obtain E. cordata nests, trap nests consisting of bamboo canes and small wooden boxes with a circular entrance measuring $1.2 \mathrm{~cm}$ (Garofalo et al. 1993) were displayed in different urban areas of three cities in the state of São Paulo, Brazil: São Carlos (21 $59^{\prime \prime} 0.091^{\prime \prime}$ S, $47^{\circ} 52^{\prime \prime}$ 47.721" W, campus of Federal University of São Carlos (UFSCar), and $21^{\circ} 59^{\prime \prime} 16.584^{\prime \prime} \mathrm{S}, 47^{\circ} 52^{\prime \prime}$ $23,456^{\prime \prime} \mathrm{W}$, private property in the city center) and Ribeirão Preto in the campus of University of São Paulo ( $21^{\circ} 09^{\prime \prime} 46.0^{\prime \prime}$ S, $47^{\circ} 51^{\prime \prime} 39.4^{\prime \prime}$ W). Traps were also placed in a Barbados cherry (Malpighia emargitata) orchard ( $23^{\circ} 02^{\prime \prime} 49^{\prime \prime} \mathrm{S}, 47^{\circ} 13^{\prime \prime} 17^{\prime \prime}$ 
W) with an area of 3 ha in the municipality of Indaiatuba, state of São Paulo. The trap nests were placed in specific sites to protect them from bad weather, taking advantage of the local buildings. In Indaiatuba, however, the traps (360 sections of bamboo cane and 12 boxes) were placed on six iron supports installed throughout the orchard.

Monthly, from December 2012 to December 2014, traps containing nests were taken to the laboratory located at the campus of the University of São Paulo, Ribeirão Preto, to monitor development. In the laboratory, nests established in bamboo were transferred to observation boxes covered with a glass plate. For those established in wooden boxes, the boxes themselves served for observation purposes. Observations of the activities of the bees were made through the covering glass plate. The observations allowed the identification of DF and SFs. Identification was facilitated by marking the scutellum region with different colors using a permanent marker.

\subsection{Estimation of reproductive skew}

Eleven of the 13 nests where one or more reactivation processes were monitored showed favorable conditions to perform estimates of reproductive skew. Females responsible for the last reactivation in the nests were collected for relatedness estimates. The entrances of the nests were then closed and the offspring was subsequently collected immediately following emergence. The reactivating females and offspring were sacrificed at a low temperature, placed in $100 \%$ ethanol, and stored at $-20{ }^{\circ} \mathrm{C}$.

\subsubsection{Relatedness estimates using microsatellite markers}

The maternity of the offspring was attributed to one of the females after a Mendelian segregation analysis at 12 microsatellite loci. The maternity of a male was attributed to one female when it shared all its alleles exclusively with that female, whereas the maternity of a female was attributed to one of the presumed mothers following the identification of the paternal allele and subsequent determination of shared alleles.
Total DNA of the individuals was extracted for the amplification of the microsatellite loci. Extraction was performed using the three right legs of adults, which were macerated in liquid nitrogen using the Chelex 100 protocol (Walsh et al. 1991). Twelve microsatellite loci were used: eight (Egc 17, Egc 18, Egc 24, Egc 26, Egc 30a, Egc 35, Egc 37, and Egc 51) described for E. cordata (Souza et al. 2007) and four (ann 3, ann 4, ann 8 and ann 24) described for Euglosa annectans (Paxton et al. 2009). The conditions for the polymerase chain reactions (PCR) were based on protocols described by Souza et al. (2007) and Paxton et al. (2009). Genotyping of the loci was performed following the run of the samples in a MegaBACE 1000 automatic sequencer (GE). The electropherograms were read with the MegaBACE Fragment Profiler program, version 1.2. Expected heterozygosity (HE) at the different loci was estimated using the TFPGA program (Miller 1997), considering all individuals analyzed as a single population.

\subsubsection{Combining behavioral and genetic data}

Observational data, such as the type of association established between reactivating females, behaviors of SFs and DFs, and identification of the cells in which each female worked, were combined with relatedness data for the definition of reproductive skew. The relatedness analysis was aimed to answer the following questions: (i) Is the SF that provisioned one or more cells and subsequently laid eggs the mother of the individuals that emerged from these cells? (ii) If the maternity of the individuals cannot be attributed to the SF that worked on the cells, could it be attributed to the DF? Thus, the relatedness analysis provided indirect estimates of the number of cases of oophagy inside the nests.

\section{RESULTS}

\subsection{Nests}

Twenty E. cordata nests were obtained, five in bamboo canes, and 15 in wooden boxes. When the nests were taken to the laboratory, the foundress females were present in 12 nests and 
they had disappeared from two nests. In the remaining six nests, the presence of more than one female, the number of cells constructed, or the occurrence of emergences indicated that they had been reactivated. Of these six nests, three had one female, two had two females, and no female was found in the sixth nest (Table I).

Table I. Date and sites of collection of the E. cordata nests and nest contents at the time of collection.

\begin{tabular}{|c|c|c|c|}
\hline \multirow{2}{*}{$\begin{array}{l}\text { Nest } \\
\text { code }\end{array}$} & \multirow{2}{*}{$\begin{array}{l}\text { Collection } \\
\text { date }\end{array}$} & \multicolumn{2}{|c|}{ Nest content } \\
\hline & & $\begin{array}{l}\text { Number of } \\
\text { females }\end{array}$ & $\begin{array}{l}\text { Number } \\
\text { of cells }\end{array}$ \\
\hline $\mathrm{CS} 1^{\mathrm{b}, \mathrm{e}}$ & $20 / 02 / 2013$ & $1^{\mathrm{g}}$ & $3^{\mathrm{h}} ; 6^{\mathrm{j}}$ \\
\hline $\mathrm{CS} 2^{\mathrm{a}}$ & $08 / 03 / 2013$ & 0 & $3^{\mathrm{h}} ; 4^{\mathrm{j}}$ \\
\hline $\mathrm{CR} 1^{\mathrm{c}, \mathrm{e}}$ & $13 / 03 / 2013$ & 0 & $14^{\mathrm{h}} ; 2^{\mathrm{j}}$ \\
\hline $\mathrm{CR} 2^{\mathrm{c}, \mathrm{e}}$ & $18 / 03 / 2013$ & $1^{\mathrm{g}}$ & $?^{\mathrm{k}}$ \\
\hline $\mathrm{CR} 3^{\mathrm{c}, \mathrm{e}}$ & $18 / 03 / 2013$ & $1^{\mathrm{g}}$ & $?^{\mathrm{k}}$ \\
\hline $\mathrm{CS} 3^{\mathrm{b}, \mathrm{e}}$ & $10 / 04 / 2013$ & $2^{\mathrm{g}}$ & $2^{\mathrm{h}} ; 2^{\mathrm{j}}$ \\
\hline $\mathrm{CR} 4^{\mathrm{h}}$ & $14 / 04 / 2013$ & $1^{\mathrm{f}}$ & $7^{\mathrm{h}}$ \\
\hline $\mathrm{CI} 1^{\mathrm{d}}$ & $03 / 05 / 2013$ & 0 & $14^{\mathrm{h}} ; 5^{\mathrm{j}}$ \\
\hline $\mathrm{C} 12^{\mathrm{d}}$ & $03 / 05 / 2013$ & $1^{\mathrm{f}}$ & $14^{\mathrm{h}}$ \\
\hline $\mathrm{CR} 5^{\mathrm{h}}$ & $17 / 06 / 2013$ & $1^{\mathrm{f}}$ & $4^{\mathrm{h}}$ \\
\hline $\mathrm{CS} 4^{\mathrm{a}, \mathrm{e}}$ & $26 / 06 / 2013$ & $2^{\mathrm{g}}$ & $6^{\mathrm{i}} ; 1^{\mathrm{j}}$ \\
\hline $\mathrm{CS}^{\mathrm{a}}$ & $09 / 11 / 2013$ & $1^{\mathrm{f}}$ & $6^{\mathrm{h}}$ \\
\hline $\mathrm{CR} 6^{\mathrm{c}}$ & $07 / 01 / 2014$ & $1^{\mathrm{f}}$ & $9^{\text {h }}$ \\
\hline $\mathrm{CR} 7^{\mathrm{c}}$ & $15 / 01 / 2014$ & $1^{\mathrm{f}}$ & $8^{\mathrm{h}}$ \\
\hline $\mathrm{CR} 8^{\mathrm{c}}$ & $28 / 01 / 2014$ & $1^{\mathrm{f}}$ & $8^{\mathrm{h}}$ \\
\hline $\mathrm{CS}^{\mathrm{a}}$ & $16 / 01 / 2014$ & $1^{\mathrm{f}}$ & $6^{\mathrm{h}} ; 1^{\mathrm{i}}$ \\
\hline $\mathrm{CS}^{\mathrm{a}}$ & $11 / 04 / 2014$ & $1^{\mathrm{f}}$ & $9^{\mathrm{h}}$ \\
\hline $\mathrm{CS}^{\mathrm{a}}$ & $04 / 06 / 2014$ & $1^{\mathrm{f}}$ & $4^{\mathrm{h}} ; 1^{\mathrm{i}}$ \\
\hline $\mathrm{CR}^{\mathrm{c}}$ & $04 / 06 / 2014$ & $1^{\mathrm{f}}$ & $3^{\mathrm{h}}$ \\
\hline $\mathrm{CR} 10^{\mathrm{c}}$ & $21 / 08 / 2014$ & $1^{\mathrm{f}}$ & $4^{\mathrm{h}}$ \\
\hline
\end{tabular}

${ }^{\mathrm{a}}$ Campus of UFSCar (São Carlos, SP)

${ }^{\mathrm{b}}$ Private property in the city center (São Carlos, SP)

${ }^{\mathrm{c}}$ Campus of USP, Ribeirão Preto (SP)

${ }^{\mathrm{d}}$ Indaiatuba (SP)

${ }^{\mathrm{e}}$ Nests with evidences of reactivation

${ }^{\mathrm{f}}$ Foundress female in the nest

${ }^{\mathrm{g}}$ Reactivating females in the nest

${ }^{\mathrm{h}}$ Closed cells

${ }^{\mathrm{i}}$ Cell in provisioning

${ }^{\mathrm{j}}$ Open cells, from which had already emerged individuals

${ }^{\mathrm{k}}$ It was not possible to count the cells, due to the deteriorating state

\subsection{Reactivation processes}

Thirteen of the nests collected were reactivated, five of which were reactivated more than once, resulting in 20 reactivation processes observed. Thirteen out of them involved two $(n=13)$ or three females $(n=3)$; the remaining processes involved only one female. In nests where more than one reactivation process was observed, the type of association between females was established whenever the previous reactivation occurred in the presence of a single female. Thus, only one mother was responsible for the offspring in such situations. In the reactivation processes monitored, associations between mother and daughter, two sisters, or unrelated females were found. It was not possible to determine the type of association between females for two reactivation processes, because the previous reactivations occurred in the presence of more than one female (Table II).

The association between unrelated females resulted from a nest usurpation. During an association between sisters, a third usurping female invaded the nest, killed the DF, and assumed that role. The SF remained doing its activities without responding to the aggressions of the usurping female.

\subsection{Behavior of females during associations}

In all associations, there was only one DF: the mother in matrifilial associations or the older female in sororal associations or associations between females of the same generation. However, reactivations also occurred in the presence of one or more SFs. The DF rarely left the nest, remained at the nest entrance most of the time while the SF was in the field, and occasionally performed oophagy in the cells closed by the SF. The SFs constructed new cells, prepared old cells for reuse, and provisioned the cells and laid eggs. Agonistic interactions were frequently observed and such behavior was always exhibited by the DF against the subordinate.

\subsection{Intranidal genetic structure}

Forty-seven males and 61 females were analyzed at the 12 microsatellite loci. HE of the markers ranged from 0.31 to 0.86 and three to 
Table II. Reactivation process, number of females, type of association established between females during the reactivations, and number of operculated cells during each reactivation. $D F$ dominant female, $S F$ subordinate female.

\begin{tabular}{|c|c|c|c|}
\hline Nest code & Reactivation process (females) & Type of association between females & Number of operculated cells \\
\hline $\mathrm{CR} 2$ & $\mathrm{R} 1(\mathrm{DF}+\mathrm{SF})$ & Sister-sister & 6 \\
\hline \multirow[t]{2}{*}{ CR3 } & $\mathrm{R} 1$ & - & 6 \\
\hline & $\mathrm{R} 2(\mathrm{DF}+\mathrm{SF})$ & Sister-sister and unrelated & 13 \\
\hline CS5 & $\mathrm{R} 1(\mathrm{DF}+\mathrm{SF})$ & Sister-sister & 8 \\
\hline CR1 & $\mathrm{R} 1(\mathrm{DF}+\mathrm{SF})$ & Mother-daughter & 6 \\
\hline \multirow[t]{3}{*}{ CR4 } & $\mathrm{R} 1(\mathrm{DF}+\mathrm{SF})$ & Mother-daughter & 2 \\
\hline & $\mathrm{R} 2(1)$ & - & 4 \\
\hline & $\mathrm{R} 3(\mathrm{DF}+\mathrm{SF})$ & Mother-daughter & 11 \\
\hline CR5 & $\mathrm{R} 1(\mathrm{DF}+\mathrm{SF})$ & Mother-daughter & 11 \\
\hline \multirow[t]{2}{*}{ CR6 } & $\mathrm{R} 1(\mathrm{DF}+2 \mathrm{SF})$ & Mother-daughter & 13 \\
\hline & $\mathrm{R} 2(\mathrm{DF}+\mathrm{SF})$ & $?$ & 12 \\
\hline CR7 & $\mathrm{R} 1(\mathrm{DF}+\mathrm{SF})$ & Sister-sister & 8 \\
\hline \multirow[t]{2}{*}{ CS6 } & $\mathrm{R} 1$ & - & 8 \\
\hline & $\mathrm{R} 2(\mathrm{DF}+2 \mathrm{SF})$ & Mother-daughter & 8 \\
\hline CR9 & $\mathrm{R} 1(\mathrm{DF}+\mathrm{SF})$ & Mother-daughter & 6 \\
\hline CS8 & $\mathrm{R} 1(\mathrm{DF}+\mathrm{SF})$ & Mother-daughter & 7 \\
\hline \multirow[t]{3}{*}{ CR8 } & $\mathrm{R} 1$ & - & 4 \\
\hline & $\mathrm{R} 2(\mathrm{DF}+\mathrm{SF})$ & Sister-sister & 9 \\
\hline & $\mathrm{R} 3(\mathrm{DF}+\mathrm{SF})$ & $?$ & 15 \\
\hline CR10 & $\mathrm{R} 1(\mathrm{DF}+2 \mathrm{SF})$ & Mother-daughter & 9 \\
\hline
\end{tabular}

12 alleles per locus were found (Supplementary material: Table SI), a polymorphism level adequate for the genetic analysis was made.

In three (CR6, CS5, and CS8) of the 11 nests with offspring and females from the most recent reactivation sacrificed, although the reactivations occurred in the presence of two females (dominant and subordinate), only the DF was collected because the SF was not found in the nest at the time of collection. In nest CS6, the DF and only one of the two SFs were collected because the other SF was not in the nest at the time of collection.

In nests CR8, CR9, CR3, CR4, CR5, CR7, and CR10, all the offspring was attributed to the DF, with the exception of one male in nest CR5, which exhibited alleles shared with both females at the 12 loci analyzed. As all these individuals emerged from cells oviposited by SFs, the results demonstrate that the DF performed oophagy and replaced all the eggs of the SFs with her own, resulting in a complete reproductive skew. In nest CS6, in which only one of the two SFs was collected, the three individuals that emerged from the cells oviposited by the analyzed SF were offspring of the DF. Considering the cells closed by the uncollected SF, there was no indication that the individuals that emerged from these cells were not offspring of the DF.

In nest CR10, the older sister assumed the role of DF following the death of the original DF and the younger sister continued to exhibit a SF behavior. The Mendelian analysis of microsatellite loci Egc 17, Egc 35, and Egc 26 confirmed that the two individuals from the offspring produced after the death of the original DF and those emerged from cells established by the younger sister were actually the offspring of the older sister (Supplementary material: Table SII), evidencing that the older sister performed oophagy of the younger sister's eggs, replacing them with her own. 
Nest CR3 was invaded by a usurping female and the offspring following this invasion was attributed to this female. Moreover, the Mendelian analysis demonstrated that the one female that emerged from a cell closed 2 days prior to the invasion was also the daughter of the usurping female, indicating the invading female performed oophagy in cells established after the invasion as well as one cell established before the invasion.

In nest CR8, the type of female association was unknown, as the reactivation previous to the genetically analyzed reactivation occurred in the presence of more than one female. However, observational data and Mendelian analysis allow the inference of relationships between them. The first reactivation occurred in the presence of a single female that was not involved in the second reactivation process, which occurred in the presence of two sisters. After provisioning and closing six cells in the presence of the DF, the SF worked alone when the last three cells were closed and the DF was no longer in the nest. The third reactivation occurred in the presence of two females - one having emerged from a cell that had been closed when the DF was still in the nest and the second one emerged from a cell closed when the DF was no longer in the nest. Thus, if the DF performed oophagy of the SF's eggs, as our results have showed, the females of the third reactivation were cousins. As we can see in Supplementary material: Table SIII, the dominant and SFs did not share alleles at loci Egc 17 or ann 24, which excludes the possibility that they were sisters, since sisters would share at least the paternal allele due to the monandric behavior of the females.

In nests CS5, CS8, and CR6, from which only the DF was collected, maternity of all the offspring was attributed to the captured DF, since all males shared alleles at all loci with her, whereas the daughters shared at least one allele with the DF.

The type of female association in nest CR6 could not be determined, as the SF was not collected and our observations did not allow us to identify it. However, as our results revealed that the DF performed oophagy of all the SF's eggs, we can suppose that the female association in this nest was sororal, since the prior association had been matrifilial and the mother was not involved in this reactivation.
Although only one of the females in nests CS5, CS8, and CR6 had been captured, the analyses justify the attribution of the maternity of the offsprings to the female captured inside each nest. This conclusion would not be possible only if the uncollected female shared the same alleles at the 12 loci analyzed with the collected female, which is not possible in a matrifilial association (CS8) and highly unlikely in a sororal association (CS5 and CR6), considering the high heterozygosity level found at the markers analyzed.

So, the Mendelian segregation at the 12 microsatellite loci consistently showed that to a DF mated with a single male could be attributed all the progenies analyzed. Moreover, in cases of sororal associations between reactivating females, the Mendelian analyses indicate that the females were full sisters, which also suggests a monandrous mating of their mothers, revealing a complete reproductive skew in E. cordata.

\section{DISCUSSION}

\subsection{Nest reactivation processes}

Reactivations of a nest by one or more euglossine females from successive generations have been reported for E. cordata (this study; Garófalo 1985; Augusto and Garófalo 2011), Euglossa atroveneta (Ramírez-Arriaga et al. 1996), Euglossa townsendi (Augusto and Garófalo 2004), Euglossa fimbriata (Augusto and Garófalo 2009), Euglossa viridissima (Cocom Pech et al. 2008), and Euglossa melanotricha (Andrade-Silva and Nascimento 2012; Andrade et al. 2016).

Considering social structure, E. cordata behavior is similar to what was observed in E. fimbriata and E. atroveneta (RamírezArriaga et al. 1996; Augusto and Garófalo 2009). E. melanotricha shares with E. cordata traits such as agonistic interactions and a single DF in the nest. However, older individuals are not always the DFs in E. melanotricha (AndradeSilva and Nascimento 2012; Andrade et al. 2016) as seen in E. cordata. Moreover, the behavioral patterns exhibited by E. townsendi and Euglossa truncata females are quite different from those exhibited by E. cordata females 
(Braga and Garófalo 1998; Augusto and Garófalo 2004). No agonistic interactions occur in E. townsendi nests. Intranidal observations reveal one female performing oophagy followed by oviposition in cells provisioned and closed by other females, and change from dominant to subordinate behavior can occur in E. townsendi nests (Augusto and Garófalo 2004). No agonistic interactions with physical contact between females are reported for E. viridissima (Cocom Pech et al. 2008). However, the comparison of this species with others of the genus is limited due to behavioral studies restricted to matrifilial associations.

\subsection{Sociogenetic structure}

The Mendelian analyses of the offspring produced by DFs indicated monandry, which is in accordance with previous studies (Souza 2007; Zimmermann et al. 2009; Oi 2010). Monandrous mating is commonly reported in Hymenoptera (Hughes et al. 2008; Strassmann 2001), and this is the ancestral condition in corbiculate bees (Hughes et al. 2008). Single-mate systems promote closer genetic relationships among nestmates and favor kin selection, a key to evolution of eusociality (Hughes et al. 2008; Otero et al. 2008).

The monandric mating of Euglossini females has been associated with the collection by males of the tribe of aromatic compounds from many families of angiosperms, especially Orchidaceae (Zimmermann et al. 2009). It was stated that males transform these fragrances into sex pheromones to attract females (Dressler 1982; Williams and Whitten 1983), or they use these compounds to attract other males, forming "leks" to which females are attracted (Dodson et al. 1969; Peruquetti 2000; Eltz et al. 2003). A third proposal states that a greater capacity to collect aromatic compounds is an honest sign of the male genetic quality when female chooses her sexual partner (Zimmermann et al. 2009).

\subsection{Reproductive skew}

Our findings agree with previous studies about a complete reproductive skew in E. cordata (Garófalo 1985; Garófalo 1992; Augusto and
Garófalo 2011). Therefore, our analyses indicate absence of relationship between genetic relatedness and reproductive skew in the different types of female associations. These findings are inconsistent with the predictions of the concession (positive correlation between genetic relatedness and reproductive skew) and restriction (a negative correlation between genetic relatedness and reproductive skew) models (Reeve and Keller 2001; Johnstone and Cant 1999a). On the other hand, compromise models predict no or negative correlation between genetic relatedness and reproductive skew (Reeve and Keller 2001; Cant 1998; Reeve et al. 1998; Johnstone and Cant 1999b) and absence of hierarchy between dominant and SFs (Reeve et al. 1998), a condition seen in E. cordata nests. In this sense, concession and restriction models fit better, as they predict such a hierarchy (Reeve and Keller 2001; Cant 1998; Reeve et al. 1998; Johnstone and Cant 1999b).

The bidding game, an extension of the concession model, predicts no association between genetic relatedness and reproductive skew (Reeve and Keller 2001) and a higher frequency of associations between unrelated females (Reeve and Keller 2001), what is in disagreement with our findings that these associations are uncommon in E. cordata .

According to Augusto and Garófalo (2011), the concession model is more adequate for explaining the social structure of $E$. cordata nests. However, our data do not support this statement. Although associations between related females are common, reproductive skew rates are not associated with relatedness in E. cordata. According to Cocom Pech et al. (2008), genetic relatedness may have been important to the evolution of social behavior, but coercive factors may have subsequently emerged, thereby strengthening cooperation between females of the genus Euglossa .

In matrifilial associations, the mother is always the DF in all Euglossa species with some level of reproductive division of labor. If high genetic relatedness is a favorable condition for the emergence of the reproductive division of labor, this situation seems to be consistent with our observations. Given the monandry of females, the mother produces sisters $(r=0.75)$ and brothers $(r=0.25)$ of the SFs and the degree of indirect fitness is high. 
In E. viridissima, all the offspring could be imputed to the original mother when she associates with only a daughter. In the presence of two daughters, however, no complete reproductive skew was found (Cocom Pech et al. 2008). The presence of aggression in E. cordata and its absence in $E$. viridissima nests seem to indicate that aggression is a coercive mechanism in E. cordata that ensures complete reproductive skew in favor of the $\mathrm{DF}$, even in associations with more than one daughter. After a coercive mechanism was established, the social structure can become somewhat more fixed and complete reproductive skew occurs, even when genetic relatedness is lower. Transactional models of concession and restriction state that a high degree of relatedness between members of a group favors the emergence of aggression which, in turn, favors a high rate of reproductive skew (Reeve and Keller 2001). Favorable conditions to the emergence of aggression are found in E. cordata, given the high frequency of matrifilial and sororal associations. Thus, the complete reproductive skew found in this species may be associated to aggression within the nests.

Besides the high frequency of associations between related females, one cannot overlook the fact that colonies of the genus Euglossa exhibit a cycle in which genetic relatedness is constantly being reestablished. Whenever genetic relatedness is diluted, it is reestablished at each reactivation performed by a single female. This condition lowers the relevance of particular situations of low relatedness.

Complete reproductive skew irrespective of the relatedness level between reactivating females, a well-defined hierarchy between reactivating females, and a low frequency of associations between unrelated females are traits shown by E. cordata, which could not be associated with a single model of reproductive skew. Rather, its sociogenetic structure includes predictions of both the transactional and compromise models. This finding shows that there is a higher variation in the kinds of social organization in these bees. Further studies are required to develop new skew models that can explain a possible species idiosyncratic nature of the social organization in these bees.

\section{ACKNOWLEDGEMENTS}

We thank the Fundação de Amparo à Pesquisa do Estado de São Paulo (FAPESP) for the financial support to this project $(2011 / 21501-2)$ and for the scholarship grant to G.A. Freiria (2011/13363-9). We are grateful for to Isabel C. Godoy and José C. Serrano for the technical help and Katia M. Ferreira for the help in genotyping. We gratefully acknowledge two anonymous referees for their comments and suggestions.

Contributions Gabriele Antico Freiria, Carlos Alberto Garófalo, and Marco Antonio Del Lama: project design, collection and analysis of data, and writing of the manuscript

Le comportement social primitif d' Euglossa cordata (Hymenoptera, Apidae: Euglossini): une vue issue de la perspective de la théorie de la sélection de parentèle et des modèles de biais reproductif

structure sociogénétique / microsatellites / liens de parenté

Das primitiv soziale Verhalten von Euglossa cordata (Hymenoptera, Apidae, Euglossini): Ein Review aus der Sicht der Verwandtenselektionstheorie und reproduktiver Skew-Modelle

Euglossa/ reproduktives Skew-Modell/ Mikrosatelliten/ soziale Struktur

\section{REFERENCES}

Andrade-Silva, A.C.R., Nascimento, F.S. (2012) Multifemale nests and social behavior in Euglossa melanotricha (Hymenoptera, Apidae, Euglossini). J. Hymenopt. Res. 26, 1-16.

Andrade, A.C.R., Miranda, E.A., Del Lama, M.A., Nascimento, F.S. (2016) Reproductive concessions between related and unrelated members promote eusociality in bees. Sci. Rep. DOI: 10.1038/srep26635

Augusto, S.C., Garófalo, C. A. (2004) Nesting biology and social structure of Euglossa (Euglossa) townsendi Cockerell (Hymenoptera, Apidae, Euglossini). Insect. Soc. 51, 400-409.

Augusto, S.C., Garófalo, C.A. (2009) Bionomics and sociological aspects of Euglossa fimbriata (Apidae, Euglossini). Genet. Mol. Res. 8, 525-538. 
Augusto, S.C., Garófalo, C.A. (2011) Task allocation and interactions among females in Euglossa carolina nests (Hymenoptera, Apidae, Euglossini). Apidologie 42, $162-173$.

Braga, A.K., Garófalo, C.A. (1998) Aspectos da estrutura social de Euglossa truncata (Hymenoptera, Apidae, Euglossini). Anais do III Encontro Sobre Abelhas, Ribeirão Preto, Brazil.

Cant, M.A. (1998) A model for the evolution of reproductive skew without reproductive suppression. Anim. Behav. 55, 163-169.

Cocom Pech, M.E., May-Itzá, W.D.J., Medina Medina, L.A., Quezada-Euán, J.J.G. (2008) Sociality in Euglossa (Euglossa) viridissima Friese (Hymenoptera, Apidae, Euglossini). Insect. Soc. 55, 428-433.

Dodson, C.H., Dressler, R.L., Hills, H.G., Adams, R.M., Williams, N.H. (1969) Biologically active compounds in orchid fragrances. Science 164, 1243-1249.

Dressler, R.L. (1982) Biology of orchid bees (Euglossini). Annu. Rev. Ecol. Syst. 13, 373-394.

Eltz, T., Roubik, D.W., Whitten, M.W. (2003) Fragrances, male display and mating behaviour of Euglossa hemichlora: a flight cage experiment. Physiol. Entomol. 28, 251-260.

Freeman, S., Herron, J.C. (2009) Análise Evolutiva, 4th ed., Artmed, Porto Alegre.

Garófalo, C.A. (1985) Social structure of Euglossa cordata nests (Hymenoptera: Apidae: Euglossini). Entomol. Gen. 11, 77-83.

Garófalo, G.A. (1992) Comportamento de nidificação e estrutura de ninhos de Euglossa cordata (Hymenoptera: Apidae: Euglossini). Rev. Bras. Biol. 52, 187-198.

Garófalo, C.A. (2006) Comportamento social nos Euglossini (Hymenoptera, Apidae). Anais do VII Encontro Sobre Abelhas, Ribeirão Preto, Brazil.

Garófalo, C.A., Camillo, E., Serrano, J.C., Rêbelo, J. M. M. (1993) Utilization of trap nests by Euglossini species (Hymenoptera: Apidae). Rev. Bras. Biol. 53, 177-187.

Hamilton, W.D. (1964) The Genetical Evolution of Social Behaviour. J. Theor. Biol. 7, 17-52.

Hughes, W.H.O, Oldroyd, B. P., Beekmanm, M., Ratnieks, F.L.W. (2008) Ancentral monogamy shows kin selection is key to evolution of eusociality. Science 320, 1213-1216.

Johnstone, R.A., Cant, M.A. (1999a) Reproductive skew and the threat of eviction: a new perspective. Proc. R. Soc. Lond. B, 266, 275-279.

Johnstone, R.A., Cant, M.A. (1999b) Reproductive skew and indiscriminate infanticide. Anim. Behav. 57, 243249.

Keller, L., Chapuisat, M. (1999) Cooperation among selfish individuals in insect societies. BioScience 49, 899-909.

Liao, X., Rong, S., Queller, D. C. (2015) Relatedness, conflict, and the evolution of eusociality. PLoS Biol. $13,1-14$.
Michener, C.D. (2007) The Bees of the World, 2nd ed., Johns Hopkins University Press, Baltimore.

Miller, M.P. (1997) Tools for population genetic analyses (TFPGA) 1.3: A Windows program for the analysis of allozyme and molecular population genetic data. Computer software distributed by the autor.

Oi, C.A. (2010) Estrutura sociogenética de ninhos de Euglossini (Hymenoptera: Apidae) e estrutura genética das populações urbanas de Euglossa cordata do Estado de São Paulo. M.Sc. Thesis, Universidade Federal de São Carlos, São Carlos, Brazil.

Otero, J.T., Ulloa-Chacón, P., Silverstone-Sopkin, P., Giray, T. (2008) Group nesting and individual variation in behavior and physiology in the orchid bee Euglossa nigropilosa Moure (Hymenoptera, Apidae). Insect. Soc. 55, 320-328.

Paxton, R.J., Zobel, M.U., Steiner, J., Zillikens, A. (2009) Microsatellite loci for Euglossa annectans (Hymenoptera: Apidae) and their variability in other orchid bees. Mol. Ecol. Resour. 9, 1221-1223.

Peruquetti, R.C. (2000) Functional of fragrances collected by Euglossini males (Hymenoptera: Apidae). Entomol. Gen. 25, 33-37.

Queller, D.C., Strassman, J. E. (1998) Kin selection and social insects. BioScience 48, 165-175.

Ramírez, S., Roubik, D.W., Skov, C., Pierce, N.E. (2010) Phylogeny, diversification patterns and historical biogeography of euglossine orchid bees (Hymenoptera: Apidae). Biol. J. Linn. Soc. 100, 552-572.

Ramírez-Arriaga, E., Cuadriello-Aguilar, J.I., Hernández, E.M. (1996) Nest structure and parasite of Euglossa atroveneta Dressler (Apidae: Bombinae: Euglossini) at Unión Juárez, Chiapas, México, J. Kans. Entomol. Soc. 69, 144-152.

Reeve, H.K., Emlen, S.T., Keller, L. (1998) Reproductive sharing in animal societies: reproductive incentives or incomplete control by dominant breeders? Behav. Ecol. 9, 267-278.

Reeve, H.K., Keller, L. (2001) Tests of reproductive skew models in social insects. Annu. Rev. Entomol. 46, 347-385.

Rehan, S.M., Tierney, S.M., Wcislo, W.T. (2015) Evidence for social nesting in Neotropical ceratine bees. Insect. Soc. 62, 465-469.

Souza, R.O. (2007) Estrutura genética e sociogenética das populações e ninhos de Euglossini (Hymenoptera: Apidae) determinadas por meio de marcadores microssatélites. PhD Thesis, Universidade Federal de São Carlos, São Carlos, Brazil.

Souza R.O., Cervini, M., Del Lama, M.A., Paxton, R.J. (2007) Microsatellite loci for euglossine bees (Hymenoptera, Apidae). Mol. Ecol. Notes. 7, 1-5.

Strassmann, J.E. (2001) The rarity of multiple mating by females in the social Hymenoptera. Insect. Soc. 48, 113. 
Strassmann, J.E., Page, R.E., Robinson, G.E., Seeley, T.D. (2011) Kin selection and eusociality. Nature 471, E5E6.

Walsh, P.S., Metzger, D.A., Higuchi, R. (1991) Chelex® 100 as a medium for simple extraction of DNA for PCR-based typing from forensic material. Bio Techniques 10, 506-513.
Williams, N.H., Whitten, W.M. (1983) Orchid floral fragrances and male euglossine bees: methods and advances in the last sesquidecade. Biol. Bull. 164, 355395.

Zimmermann, Y., Roubik, D.W., Quezada-Euan, J.J.G., Paxton, R.J., Eltz, T. (2009) Single mating in orchid bees (Euglossa, Apinae): implications for mate choice and social evolution. Insect. Soc. 56, 241-249. 